\title{
Evaluating resistances to health promotion campaigns with Discourse Analysis \\ Evaluación de resistencias a campañas de promoción de salud mediante el Análisis del Discurso
}

Stéphanie Lyanie de Melo e Costa ${ }^{a}$, Wedencley Alves ${ }^{b}$

a Stricto Sensu Graduate Program in Health Information and Communication, Oswaldo Cruz Foundation, Brazil

${ }^{\text {b }}$ Stricto Sensu Graduate Program in Communications, Federal University of Juiz de Fora, Brazil

\begin{abstract}
Introduction: This paper argues the role of Discourse Analysis - DA (Michel Pêcheux, Eni Orlandi) as a theoretical-methodological contribution to the evaluation of health campaigns. Objectives: It shows how DA can be applied to identify and understand discourses of resistance to health promotion campaigns. Methodology: It analyses the HIV prevention campaign of the Brazilian Ministry of Health designed for the carnival of 2010 , as well as individual interviews with two people living with HIV. Results: By comparing the discourses mapped in the campaign and those present in the interviews, some dissonance of senses, understood as forms of resistance, are identified. Discussion: Such results also lead to the discussion regarding biopower issues (Michel Foucault) and the relationship between power and resistance in historical processes of subjectivation. Conclusion: It is concluded that, before trying with campaigns to change individual's practices towards behaviors that promote health, institutional practices must be changed in order to prioritize listening to people when designing such campaigns, by applying Discourse Analysis's theoretical-methodological contributions.
\end{abstract}

Keywords: Discourse Analysis; Health promotion campaign; Prevention Campaign; Biopower; HIV; Acquired Immunodeficiency Syndrome.

\section{Resumen}

Introducción: Este artículo discute el papel del Análisis del Discurso - AD (Michel Pêcheux, Eni Orlandi) como una contribución teórico-metodológica a la evaluación de campañas de salud. Objetivos: Se muestra cómo se puede aplicar AD para identificar y comprender los discursos de resistencia a campañas de promoción de salud. Metodología: Se analiza la campaña de prevención de VIH del Ministerio de Salud de Brasil hecha para el carnaval de 2010, así como entrevistas individuales con dos personas VIH positivo. Resultados: Mediante la comparación de los discursos mapeados en la campaña con los presentes en las entrevistas, se identificaron algunas disonancias de sentido que pueden ser entendidas como formas de resistencia. Discusión: Tales resultados nos llevaron también a examinar cuestiones de biopoder (Michel Foucault) y la relación entre el poder y la resistencia en la conformación de procesos históricos de subjetividad. Conclusiones: Se concluye que, antes de intentar con campañas cambiar las prácticas individuales hacia comportamientos que promuevan la salud, las prácticas institucionales deben cambiarse para priorizar la escucha de las personas al diseñar tales campañas, aplicando las contribuciones teórico-metodológicas del Análisis del Discurso.

Palabras clave: Análisis del Discurso; Campaña de Salud; Campaña de prevención; Biopoder; VIH; síndrome de inmunodeficiencia adquirida. 


\section{Introduction}

S ince late 1980s and early 1990s, the Brazilian state has carried out massive preventive campaigns on HIV (Human Immunodeficiency Virus) 1 . Generally, social groups in which the incidence of the virus is considered a major concern are elected as the priority target audience for these campaigns. The campaign pieces are designed by advertising agencies hired by the government, to be conveyed in two main times of the year: Carnival and World AIDS Day. The flagship are the videos made for national television broadcast. Before campaigns are broadcast, the opinion of social representatives about them is heard, although this social achievement has been losing power in recent years. According to Alves (2015), social participation in Brazilian government publicity of public utility in health has been restricted to one organizational area (the technical area's working group), and it is not anyone who can participate, as social representatives, are chosen by the Brazilian Ministry of Health. The campaigns' efficiency is evaluated according to the data of the next annual HIVIAIDS epidemiological report and through a recall test, which is a quantitative research method of the memorization levels of brands and advertising campaigns. With some exceptions, this has been the practice regarding HIV prevention campaigns in Brazil, which seems right from the point of view of institutional communication strategies for health or health marketing. However, if the campaign strategies seem to meet a certain model of public communication, adopted worldwide, what makes them still massively face the brunt of HIV infection in certain social groups?

According to a survey conducted by the Brazilian Ministry of Health (Ministério da Saúde, 2011), Brazilians, despite being well informed by HIV prevention campaigns and understanding them, continue to have "risk" behavior (as called by health experts), including those already infected with the virus. As they can get reinfected with another strain of HIV, as well as infect someone else, they are prescribed condoms. Treatment with antiretroviral drugs is also prescribed for them, so they can prevent their organism from developing AIDS, as well as from infecting another person, because such drugs can durably suppress HIV, making it undetectable in tests, thus, untransmittable to the sexual partner (Unaids, 2018). But studies conducted in different countries and with PLHAs (people living with HIVIAIDS) of varied socio-demographic profiles show their resistance to health discourses

THIV is the virus that causes AIDS (Acquired Immunodeficiency Syndrome). But a person who has HIV does not necessarily become ill with AIDS, specially if he/she detects the infection early and stays in proper treatment with antiretroviral drugs. Thus, having HIV does not equal to having AIDS. on HIV, AIDS and self-care. In Brazil, Ivia Maksud (2007) conducted a survey with heterosexual serodiscordant couples (this means only one person has HIV) who did not always use condom. According to her, there is a gap between the population and information on HIV prevention and treatment provided by the Brazilian Ministry of Health and other organizations. Her study showed that public health precepts about risks present in the exercise of sexuality are continuously negotiated. "This process is not perceived in the same way by the partners, producing tensions and dilemmas within the couple and in the relationship with the family and with the network of sociability"2 (Maksud, 2007, p. 4). Another Brazilian study carried out with HIV patients in Juiz de Fora (Fernandes et al., 2013) found that, in nine months, $17.6 \%$ of them abandoned treatment. One of the reasons pointed out was the high life expectancy of these people, which ends up giving them the false idea that it is no longer necessary to do medical follow-up. In Australia, 30\% of the people with HIV were out of treatment because they did not know newer medications with less side-effects existed (Davey, 2012). In the United States of America, only $30 \%$ of the African-American seropositive people adhered satisfactorily to treatment against HIV, compared with $40 \%$ of non African-Americans (Kong, Nahata, Lacombe, Seiber \& Balkrishnan, 2012).

This paper aims to stimulate the debate about health prevention campaigns with the question: if communication is rather a practice of language, which is rather a production of senses, are the discourses of the campaigns being read in the way their makers want? The hypothesis was that there is a dissonance of senses between ordinary people's discourses about body, disease and health in their everyday lives and the institutionalized discourses and institutionalized knowledge that are present in the campaigns. Therefore, the issue that moves this paper is communicational and discursive.

The important health literacy deficit in Brazil is not addressed in this paper, because it alone does not explain the dissonances between what is intended to be disseminated in the campaigns against HIV and the way in which they are effectively read, as shown in a study by the Brazilian Ministry of Health (Ministério da Saúde, 2011). Our issue is not simply that people "do not know how to read" the campaigns or they "read but do not understand" them, but rather that they "read in other discursive positions" than those from which the campaigns were elaborated. People, regarded by campaigners as mere "target audien-

2Own translation, original sentence: "Tal processo não é percebido da mesma forma pelos parceiros, produzindo tensões e dilemas no casal e no relacionamento com familiares e rede de sociabilidade". 
ce" and "receptors" of a message, actually produce their own everyday senses about body, disease and health, which is often ignored by health campaigners, because people most of the time do not speak from discourses and knowledge recognized as legitimate.

This paper aims to discursively understand resistances to health campaigns. Understanding the senses assigned by their target audience to their message is more complex than applying recall tests: "The fact that the interviewee remembers an ad, for example, says nothing about changes in their behavior regarding health"3 (Alves, 2013, p. 89).

\section{Methods}

Several authors have dedicated their studies to health campaign evaluation. Adrian Bauman (2000) recommends the use of qualitative methods - such as focus groups with a sample of the target population, for example - in pre-testing health campaigns. He also suggests evaluating the impact of health messages by measuring changes in behaviors and in broader public health rates (such as morbidity rates). Noar (2011) also recommends the use of control groups and pre-tests, as well as evaluation strategies which can demonstrate that the behaviors targeted by the campaign changed as intended and in a different trend than those not targeted (Noar, Palmgreen \& Zimmerman, 2009). But Noar (2009) also emphasizes that evaluating such impact of health campaigns is usually problematic due to their broad scope (usually national), which makes it difficult to perform randomised controlled trials. The USA National Cancer Institute (2009) lists other difficulties in evaluating health campaigns, such as isolating each campaign activity component's effect and controlling external influences. As Dorfman, Ervice, \& Woodruff (2002, p. 35) stated, "As much as we'd like it to be the case, evaluations [of public campaigns] will never occur in the laboratory. [...] Conditions cannot be controlled, and so expectations for scientific rigor have to be balanced against the constraints of messy real world situations."

The European Centre for Disease Prevention and Control (2014) carried out a literature review on health communication campaign evaluation with regard to the prevention and control of communicable diseases in Europe, examining the international English-language literature published between 2000 and 2011. They found out that there are many useful frameworks, guidelines and principles for health campaign evaluation in the literature,

${ }^{3}$ Own translation, original sentence: "O fato de o entrevistado se lembrar de um anúncio, por exemplo, nada diz sobre mudanças ou não de comportamento em relação à saúde". but specific tools to assist researchers in the evaluation process are still lacking, in fact.

We advocate that Discourse Analysis (DA) is a valuable theoretical and methodological contribution to evaluate the impact of health promotion campaigns, among them, those of HIV prevention. This paper analyzes the video of the HIV prevention campaign developed by the Brazilian Ministry of Health (hereinafter $\mathrm{BMH}$ ) broadcasted at the carnival of 2010, as well as individual interviews with two HIV positive people. First, the discourses present in the campaign are mapped, in order to find out what the $\mathrm{BMH}$ proposes for PLHAs. Then, they are contrasted with the interviewees' discourses, in order to identify the dissonan$c e$ of senses that underlie individuals' resistances. Issues of biopower (Michel Foucault, 2000) and the relationship between power and resistance in the conformation of historical processes of subjectivation are also discussed. It is not possible to understand health campaigns outside the biopolitical context to which they belong. This paper presents part of unpublished results of a master's thesis ${ }^{4}$.

Debates regarding AIDS for the past almost forty years are great to observe the discourses on subjects, power, body, health and disease. Not only do they point to the place of interpretation of each social agent involved in the epidemic, but they also show the constant displacements that the same agent (for example, the Brazilian Ministry of Health, in its campaigns) performs throughout history. From the discursive point of view, both individuals and institutions occupy subject-positions in discursive formations (Pêcheux, 1997) - which are interpretive matrices, relations of senses - and are positioned within relations of force and power-ideological formations (Orlandi, 2005, p. 78).

The concept of biopower, formulated by Michel Foucault (2000), is useful to understand the issues underlying people's resistance to health campaigns in general, and in the case of this paper to the ones regarding HIV. These campaigns are biopolitics, which, in turn, do not happen without the resistance of peoples in society.

Foucault devoted much of his work to two systems of power which, according to him, emerged in the transitions between the seventeenth/eighteenth centuries and the eighteenth/nineteenth centuries: disciplinary power and biopower, respectively. Around the eighteenth century, a modality of power began to configure. Unlike deciding and ritualizing death, it began to calculate and organize the population's life in order to increase it by "making live

\footnotetext{
"In the master's thesis (Costa, 2014), the discourses of four people living with HIVIAIDS are compared with those of the AIDS campaigns carried out in Minas Gerais between 2009 and 2013 and prepared by the Brazilian Ministry of Health, by the Secretary of Health of Minas Gerais and by the Grupo Vhiver, a non-governmental organization focused on AIDS.
} 
and letting die". Death and all its ceremonial symbolism have since then been disqualified, to the extent of being, in the end of the twentieth century, more taboo than sex itself, according to Foucault (2000, pp. 295). Nowadays, death is tried to be hidden, relegated to hospitals, cemeteries or cremations, in an attempt to hide an event that our society wants to deny. Likewise, the exhibitionism of the disease is no longer admissible, and the body is valued as the place where a person should strive to appear to be in good health (Moulin, 2008, pp. 19-20).

Two models of managing the social body emerged, with a certain chronological lag, but which historically overlap and articulate. The first one is the disciplinary power, centered in the body of the individual, manipulating it in a way to make it more docile, healthy and therefore productive; exercised in schools, hospitals, barracks, factories etc. The second one is the biopower, centered not on the body (although it is exercised on it as well), but on the life of the species and the population, exercised through practices of health, birth, hygiene, classification and racial debugging etc.

Foucault calls biopolitics the mechanisms of disciplining bodies and administering populations, carried out by the bourgeois state and other spheres of power (medical knowledge, mainly), which serve to the idea that the wealth of a nation is not defined only by its resources, but mainly for the quality of its population. Therefore, all state policies to combat HIV - including prevention campaigns - are biopolitics.

Taking the debate proposed by the French philosopher from a discursive point of view, it can be affirmed that the discourses of health campaigns are materializations of an ideological formation, in this case, of biopolitics.

Contrary to some reading, for us the identification of biopolitics is not a Foucault's denunciation, but rather the characterization of a moment in history in which the western central societies are organized, rationalized and institutionalized around the medical knowledge, producing "effects of truth". So that, in the name of the medicalization of society, cleavages were made in relation to what is productive and what is not, what is allowed and what is forbidden (such as condom use and abstention of it, respectively), what is normal and what is pathological.

From the discursive point of view, both individuals and institutions that create health campaigns, by occupying subject-positions in discourses - which are always provisional, subject to historical processes, marked by incompleteness, displacements and ruptures -, produce, reproduce and also displace senses. However, the interpretation is not free, because there is a politics of sense which must be considered.

[...] there are ways of interpreting; it is not everyone who can interpret according to his/her will; there are specialists, there is a social body to which are delegated powers of interpreting (thus "assigning" senses), such as the judge, the teacher, the lawyer, the priest etc. Senses are always "administered", they are not loose. (Orlandi, 2005, p. 10)

Thus, the institutions that elaborate health campaigns, in exercising biopower, occupy this privileged place of administrating senses on the body, disease and health; on what should and should not be done to stay healthy. However, this "policy of saying" encounters resistance, produces counter-discourses and counter-identifications, because the crystallized senses are being permanently negotiated. If the places of the campaigns' readers, as much as of authors, are determined by the discursive formations where the subjects are positioned, specially taking into consideration the heterogeneity of these positions, it is assumed that the interpretation of health campaigns or health policies does not happen exactly as predicted by official or institutionalized discourses. Thus, the biopolitical discourses of health promotion campaigns - among them, the ones regarding HIV prevention (focusing on "risk behaviors and practices" and "failures" in adherence to treatment) - may be in conflict with other discourses and perceived by people as interference over their affectivities and subjectivities.

Resuming Foucault (1999), the institution of biopower results in adhesions, but also in resistances. The processes of subjectivation - the historical constitution of the subjects - is not be, therefore, unidirectional. The institution of biopower, of the disciplined and productive body, collides with desires that make the subject a transgressor of his own body, to be continually administered by the institutionalized powers. Therefore, biopolitical cleavages (allowed/forbidden, normal/pathological etc.) are not always instituted in a peaceful, inclusive and consensual way.

Individuals base their way of understanding AIDS and their daily practices in various circulating messages about the syndrome, but also in discourses about pleasure and

5 Own translation, original sentence: "[...] há modos de se interpretar, não é todo mundo que pode interpretar de acordo com sua vontade, há especialistas, há um corpo social a quem se delegam poderes de interpretar (logo de 'atribuir' sentidos), tais como o juiz, o professor, o advogado, o padre etc. Os sentidos são sempre 'administrados', não estão soltos." 
fun emitted by the media, through mechanisms of identification or counter-identification:

By exerting direct coercion on certain social groups, the AIDS information epidemic produces another counter-information epidemic. Each individual who is discriminated against or excluded by the surveillance mechanism produces its own statement of justification, defense process, a bid in the game of speech, relationship of forces that face each other. (Lima, 2006, p. 106) ${ }^{6}$

Therefore, it is fundamental to persistently monitor the movements of sense in the debates on HIV, operated by institutions and governments. But also, by what appears to be a gap in the campaigns, the modes of interpretation of what Orlandi (2004) has called "the disorganized everyday discourses", that is, discourses of the people in their ordinary lives. Hence, this paper proposes the use of the theoretical-methodological contribution of Discourse Analysis in the understanding of resistances to health campaigns, through the analysis of the discourses present in the campaigns in comparison to those identified in the interviewees' sentences.

It is important to emphasize that the object of research and analysis of DA is not the individuals interviewed, but the discourses of the society that cross them, present in their narratives, from the subject-positions occupied by them. The discursive analysis of the interviewees' speeches should mainly aim to find out how the subject-positions to which they adhere approach or distance themselves from the health campaigns that are to be evaluated, to understand why, despite communication efforts, they still resist. In addition, it should be understood that, during an interview, the formulation of sense operated by the interviewees is necessarily crossed by the imaginary projections they have with respect to who the interviewer is, and vice versa. Therefore, and necessarily, the result is rather a "discursive co-construction", as called by Guilhaumou (2007, p. 7): "It is therefore worth emphasizing the shared responsibility between the interviewer and the interviewee in the elaboration of these life histories, and more broadly in the phenomenon of discursive co-construction"7.

The discourse is the effect of senses between interlocutors - that is, it does not exist by itself, but only in a space

\footnotetext{
5 Own translation, original sentence: "Exercendo coerção direta sobre determinados grupos sociais, a epidemia de informações da AIDS produz outra epidemia de contra-informações. Cada indivíduo discriminado ou excluído pelo mecanismo de vigilância produz o seu próprio enunciado de justificação, processo de defesa, lance no jogo das falas, relação de forças que se enfrentam".

${ }^{7}$ Own translation, original sentence: "Convém, portanto, de fato, sublinhar a responsabilidade partilhada entre 0 entrevistador e 0 entrevistado na elaboração dessas histórias de vida, e mais amplamente no fenômeno da co-construção discursiva".
}

between subjects - Hence, for the discourse theory, the communicative process is not about transmitting information through a message, as assumed by the mathematical model of Shannon and Weaver (1949), for example, which quickly became a matrix that inspired a whole way of thinking about communication and public health policies in Brazil (Araujo \& Cardoso, 2007, pp. 42 and 44-45). The discourse theory neither conceives in the communicative process the separation between emitter, on the one hand, and receiver, on the other: both are, at the same time, carrying out the process of signification (Orlandi, 2005). Language is not understood as a repertoire of codes hence, transferable and decodable -. There is no transfer of meanings: the senses are, first, unstable and negotiable. Therefore, there are multiple reading possibilities of any significant material, for example, health campaigns.

This paper analyzes the discourses present in the video of the HIV prevention campaign prepared by the Brazilian Ministry of Health to be broadcast on television during the Carnival of $2010^{8}$, and contrasts them with the discourses identified in the testimonies of two HIV-positive interviewees. The purpose of the analysis is to understand the daily discourses of PLHAs and how they dialogue (resonate, resignify or deny) with the institutionalized discourses and knowledges of the campaigners against HIV. It is believed that a better understanding of the dissonances between messages and their "target audience" is important to enhance the interlocutionary relationships between these two groups of society.

PLHAs were chosen as interviewees because they have already been resistant to the campaigns and their lives are at greater risk when they do not take preventive measures (since there is the possibility of reinfection) and when they do not satisfactorily adhere to treatment. It is believed that if the discourses underlying the resistance of this group can be understood, then the resistances of the other people in society can be more easily comprehended. In addition, in our master's thesis (Costa, 2014), it was identified a major silencing in most HIV prevention campaigns made by the Brazilian Ministry of Health to be aired on TV between 2009 and 2013. PLHAs not as objects of discourses, but as subjects of their own discourses. This was another reason that encouraged us to choose them as interviewees. However, any social group can be interviewed, depending on the purpose of the campaign evaluation.

The United Nations (ONU, 2011) recommends involving more the people at greater vulnerability and PLHAs in decision-making and planning of prevention strategies for

${ }^{8}$ Watch the video on-line: http://youtu.be/pAOh6eEZP1M 
these populations. Our study, by listening to one of these groups, seeks to concretize this idea, aiming to provide subsidies for campaigns so that they can be closer to these interlocutors and to the population in general.

In addition, to "accept the community as the essential voice in matters of its health, living conditions and wellbeing" - as so well written in the Ottawa Charter (WHO, 1986) - and to promote community participation in health - a commitment made by states at international conferences and in government programs - implies that Communication recognizes and investigates the discursive mechanisms by which certain health "truths" and knowledge are imposed or questioned.

The interviews were held face-to-face, in June 2012. The interviewees were a man and a woman, both Brazilians, heterosexuals, 40-50 years-old, known to be HIVpositive, with full autonomy and members of the same non-governmental organization against AIDS in Juiz de Fora (Minas Gerais, Brazil). Excerpts of the interviews were transcribed below, in which "S." is the researcher and "A." and "F." are the man and the woman interviewed, respectively".

\section{Results}

According to the Brazilian Ministry of Health ${ }^{10}$, this campaign was a response to the growing trend of AIDS cases among 13-19 years-old girls: there were 8 cases in boys for every 10 in girls. The message for those who were going to enjoy the carnival regarded prevention. The slogan "Condom. With love, passion or just sex really. Use it always." sought to reach both lovers and those who just wanted to enjoy casual sex. Two TV films were produced: one targeting young gay people and another targeting girls. This last one is the video analyzed in this paper. In both films, the protagonist is a condom that talks and alerts young people to use condoms (Figure 1).

The film begins with an electronic soundtrack, like trance music. From above, the camera shows a nightclub. Young people have fun on the dance floor. In the center of it, there is a young white woman who has just kissed a young black man. She moves away from him, smiling, and enters the ladies' room to touch her lipstick. In this new scenario, a female voice (but it could also be a transvestite's) emerges, whispering "Hey! I'm down here.". The girl is

\footnotetext{
9n the transcript, the bars serve to show the passage from the interviewee's speech to the researcher's. The writings in square brackets are our observations, to facilitate the reader's understanding of the dialogue. The study was approved by the Research Ethics Committee of the Federal University of Juiz de Fora (UFJF). The entire interviews can be found transcript in Costa, 2014.

10 Available at: http://www.aids.gov.br/pt-br/campanha/campanhade-carnaval-camisinha-com-amor-paixao-ou-so-sexo-mesmo-usesempre-2010>. Accessed on 2 October 2018.
}

amazed and puts her hand inside her purse. From it, she takes out a yellow male condom. We hear it saying "It's hot in here!". The camera closes in the girl's hand, holding the talking condom. It says, wickedly, "Hum ... You were at a great snog over there, weren't you?", without any reproach. The camera closes in the girl, who says "Oh, he's such a hunk, right? Will it happen?". The camera closes in the condom, which says "Of course it will! You're driving him crazy.". The camera closes in the girl, who smiles satisfied. The condom says "And since the night is going to be great, don't forget me, eh? What if he has forgotten his condom... ". The girl agrees with a gesture and puts the condom back in her bag. Meanwhile, it says "Now go there, my love, and nail it!". The girl, sure of herself, finishes doing her hair in the mirror and leaves the ladies' room. The camera shows again the dance floor. The girl approaches the boy. We hear a male narrator say "Condom. With love, passion or just sex really. Use it always". The girl embraces the boy, while the campaign's website appears on the screen, as well as the logos of the Brazilian "Health Hotline" (Disque Saúde), of the Brazilian Unified Health System (SUS), of the Brazilian Special Secretariat for Policies for Women, of the Brazilian Ministry of Health and of the Brazilian Federal Government.

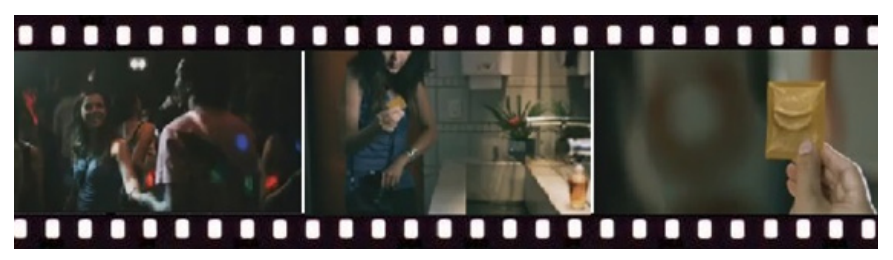

Figure 1. Frames of the HIV prevention campaign designed by the Brazilian Ministry of Health for the carnival of 2010.

This film has the biomedical discourse on prevention - that is, the one which encourages the use of condoms -. The BMH places itself as sanitary authority regulating juvenile sexuality, preaching to young women the use of male condoms in all sexual relations, "with love, passion or just sex really." Therefore, this campaign is a discourse in favor of the exercise of the female juvenile sexuality, although admitted only within the sanitary standards. This reiterates Michel Foucault's view (1999) that the device (dispositif) to control sexuality does not work through censorship, but through the proliferation of discourses about sexuality. There is a constant need to talk about "healthy" sex, in doctors' offices, in the media, in schools, in family dialogues, in health campaigns. Only in this way is it possible to know the current sexual practices, to investigate 
them and to demystify them permanently in order to control them better:

The AIDS information epidemic does not operate with the process of prohibition of orientations and behaviors, but it is much more oriented towards authorizing ways of being and acting considered safer for the control and prevention of the disease. The incentive to the use of rubber condoms should be understood in this context. (Lima, 2006, p. 125)

Although current BMH's HIV prevention campaigns do not judge sexual practices as long as condoms are used, this has not always been the case. The first prevention campaigns for the syndrome, dated from the 1980-1990 decade transition, stimulated a reduction in the number of sexual partners. When the interviewees talk about how they became infected, they dialogue with a discursive memory of association between AIDS and promiscuity, typical of these first campaigns. Now it is to confirm it or to challenge it, claiming that they have gotten HIV from their only one sexual partner. The classic association between disease/dirt and health/cleanliness also occurs:

A. -there are two brothers of mine [...], we used to go fornicate at whorehouses quite a lot in Juiz de Fora [...] And he did not get it [HIV]. I got the thing,at home. [...] / S. -And there, at the whorehouses, you also didn't wear a condom!? / A. -I didn't use it, no [...] The women there were clean.

F. -[...] That's because it [HIV] was more due to promiscuity, because it is not only transmistted through drug use.

By the campaign's slogan ("with love, passion or just sex really"), it is noted that the imagined reader are girls who do not use condoms because they love their sexual partners and trust their fidelity, thus dispensing with the need for prevention. This seems to be confirmed in the testimony of the HIV-positive woman interviewed. She comes up with some reasons why people, in general, do not use condoms. Among them are the ideal of fidelity, harmony, and the will to have a child:

F. -I would do this [today, if she was not HIV-positive]: I would have a relationship with a person using preventive methods for 1 year. And as we go living together, getting to know each other, relating in order to have a life of fidelity, affinity, living together, because the purpose of it all is getting together... after a certain time, I would take, the two of us would take an HIV test to really verify [if there was any sexually transmitted infection] [...]. Then, if there was nothing, the doctor says "everything is ok with the couple, you can be happy forever", I would not use [condoms] ... After that, the couple would want to have a child, so I could chill and have a healthy life.
This discourse, so present in our society, ends up assigning a negative sense to condoms: that the person uses it because he/she is unfaithful, especially in a society in which its contraceptive function is replaced by other methods, such as contraceptive pills:

F. -[...] at my father's time, I think, people talked about condoms, but not too much, I think. It was not much put available at the mercy of the person in pharmacies. It was all done hidden, because I think that at that time marriages were very right, very correct, and if the man were to do something [extramarital relations], people used a method like that [condom], right?, in order not to get pregnant. [...] Nowadays it is not like this anymore, there are other means, several methods to avoid [pregnancy], contraceptives, $[\ldots]$.

Another sense given to the condom is the identification of who insists on its use as an infected person. Some PLHAs stop using it for fear of having their seropositivity unraveled and thus losing their loved ones:

A. - I lived with a woman who put this [HIV] inside my home. I S: And did you know [that she had HIV]? I A: I knew not! [...] I saw her taking medicine and asked her "What are you taking medicine for?". "For my stomach!"

A. -No, I do not tell anything [to the people whom he is going to have sex with that he has AIDS]. People who want to use a condom, that's fine. Now, if they don't want to use it, I also don't say a thing.

In some couples in which only one has HIV, becoming infected is taken as proof of love, which challenges the discourse of prevention:

A. -Because ... she ended up showing me she likes me. Because, for those who love, everything is valid to get the guy, including getting HIV.

From the dialogue on the campaign's video, it can be deduced that another reader imagined by the film makers is a girl who does not use condom because she conceives as being the role of the boy to bring it with him. Therefore, in its message, the campaign seeks to encourage girls to bring the male condom, in case the boy forgets it ("And since the night is going to be great, do not forget me, eh? What if he has forgotten his condom..."). It does not, therefore, eliminate the responsibility of the boy to be the one who should have the initiative to propose the condom use, but places the girl as co-responsible for prevention.

However, the BMH neglects other reasons why people 
do not adhere to "safe sex." Our interviewees, for example, became infected because they judged by their sexual partner's physical appearance that they had no HIV.
A. -Oh, [I did not use a condom] because I thought I didn't have anything [any sexually transmitted infection]. [...] and she had nothing, either. [...] for me she was clean, for me she had nothing.

F. -After getting divorced, after 5 years, I met a person in my life who was the one who got me infected with HIV. Because until then, he had said that he had stopped using drugs because he had even dried the marks in his veins. [...] And then I was still ... ignorant of the drug issue, because I had never seen anyone use it, and I did not even practice using it. So, I was conned.

F. -Because in the matter of a few hours after meeting the person [flirting] you won't know whether she/he has the disease [AIDS] or not, and there may be an affinity [...] a physical attraction and then, if she/he has low immunity, she/he gets it [HIV].

There are cases in which people do not want to use condom because it is an accessory that bothers them and takes away the pleasure; which gives the sensation of castration to those who are using it; or does not seem natural to them:

\begin{abstract}
F. -If someone says she/he has it [a problem to enjoy pleasure with condoms], maybe it's because she/he feels that it [the condom] is taking away what nature gave him/her, right? But I think if you do it [sex] with affection, and use the condom properly, you don't lose the pleasure of feeling the same way it does without it [condom], no. [...] Except if, to man, the male condom gives that feeling of closing his whole member [penis], and he feels castrated. [...] I also used the female condom, and it gives a feeling of frustration, as men say.
\end{abstract}

Some PLHAs find it difficult to negotiate condom use, even with partners to whom they have disclosed their seropositivity. The interviewee says he prefers to use condom, in order not to re-infect himself, but his partner rejects it because the condom bothers her:

A. -I told her "you know I'm HIV positive, right?" [...] She knew it! Then I said "Let's go get a condom." Then she said "Condom hurts a lot". Then I said, "Let's do it without condom, then." [...] I said "okay, then do it without fear of getting the virus", because it's certain that afterwards it kills us faster, right? / [...] I told her "Let's start using condom always, otherwise I'm leaving". [laughters]

Another reason why some PLHAs do not use condoms is the very denial of being ill:
S. -And when do you not feel like using [condom]? And why is that? / A: Because I think wrong. Because "I'm not sick, nevermind"

F. - $[\ldots .$.$] some of the people who have the virus preserve$ themselves so as not to pass on to others, but some even pretend they do not have it [HIV] in order not to know they have it [by taking a test], and they pass it on to others [...].

In some couples in which both have HIV, even with the possibility of re-infection, the negotiation of condoms is also difficult precisely because one thinks they already have the virus:

A. -"Oh, I'm not going to use [condoms] because I already have it [HIV] anyway, so let's do it anyway." Then I get caught up in it and do it anyway.

Therefore, these are challenges to the biomedical discourse that bases preventive campaigns in general, especially to the one that regulates the allowed and the forbidden, holding the individual responsible for the care of him/herself and of the others. Such a discourse generates at least two conflicts. The first one is in the form of the law: it is this discourse of PLHA's accountability for the health of the rest of the population that underlies the criminalization of HIV transmission, with which PLHAs have been concerned:

A. -I think it [the fact he does not use a condom] complicates because the person can sue me, then I'm fucked.

The second conflict consists of the suffering, regret and guilt generated when someone becomes infected and infects someone else:

A. - I also regret for myself [for having had sex without a condom], but I regret it more for my woman, right. Beautiful woman, really beautiful, got sick [of AIDS] because we were stupid, right. I regret having put it [HIV] in her. [...] I didn't want to have put it in her, poor her. She never complained about anything with me either, but I always ... I always see a gloom in her eye. In her eye I see that it hurts her. [...] Then she says "no problem". [...] but I know that there is a problem. I didn't want to do any harm, but I don't know. I felt sorry for having put it [HIV] in her.

A. -But it [not using a condom] is a serious problem, [...] because it harms others.

\section{Discussion}

In general, Brazilian government health campaigns (including those against HIV) follow principles of social marketing, a model adopted worldwide. However, it contains much of the common commercial advertising discourse, 
in addition to sharing the developmentalist behavioral assumption that social problems (such as diseases) are caused by individuals' attitudes and preconditions (Araujo \& Cardoso, 2007, p. 110). Thus, BMH's health campaigns seek not only to sell biomedical information, but especially to transmit certain messages, advertise the condom's properties, emphasize behavior change and suggest the adoption of certain sexual practices. "There is the behaviorist assumption that advertising campaigns on TV can change Brazilian sexual behavior"11 (Paz, 2007, p. 83).

The biggest problem concerning social marketing applied to health is that, more than an instrumental model of communication, it is an ideology that does not recognize health as a citizen's right, but rather as a product to be consumed by a client. "The imposition of the marketing logic confused the idea of health promotion, emphasizing the advertising of the product (condom) associated with safe practices and behaviors that were also wanted to be sold" (Rodrigues, 2012, p. 21) ${ }^{12}$. Wildney Contrera (2005, p. 44), back in 2005 , was already concerned with the fact that HIV prevention campaigns in Brazil are developed by the same agencies that run campaigns regarding candies, margarines or banks: "If agencies treat AIDS in the same way, it can become an aggravating factor since, in fact, the product being advertised is a symbolic good and its understanding depends on the subjectivity of each person"13.

Let us ask ourselves Araujo \& Cardoso's questions (2007, p. 111): "With whom do we relate in health, with a 'client', with a 'public of consumers' or with citizens? Our goal is persuasion or interlocution? To know in order to convince, or to know in order to universalize the right to communication?"14.

This paper is not a criticism that disqualifies the elaborators of the analyzed campaign. It cannot be denied that there is a constant attempt by the State and health agents to approach society and to bring other voices to health campaigns. However, while the Brazilian government seeks to hear representatives of social groups about HIV prevention campaigns before they are broadcast, it rema-

\footnotetext{
"Own translation, original sentence: "Há o pressuposto behaviorista de que as campanhas publicitárias na tevê podem mudar o comportamento sexual brasileiro".

${ }^{12}$ Own translation, original sentence: "A imposição da lógica do marketing confundiu a ideia de promoção de saúde, enfatizando a propaganda do produto (camisinha) associada às práticas e aos comportamentos seguros que também se desejava vender".

${ }^{13}$ Own translation, original sentence: "Se as agências tratarem a aids da mesma maneira pode-se tornar um agravante já que, na verdade, o produto que está sendo veiculado é um bem simbólico e que sua compreensão depende da subjetividade de cada um".

${ }^{14}$ Own translation, original sentence: "Com quem nos relacionamos na saúde, com um 'cliente', com um 'público consumidor' ou com cidadãos? Nosso objetivo é a persuasão ou a interlocução? Conhecer para convencer ou conhecer para universalizar o direito à comunicação?".
}

ins stuck in a monological model of communication, centered on changing people's habits and behavior.

By comparing the discourses present in the video of the Brazilian Ministry of Health's HIV prevention campaign for the Carnival of 2010 and in the PLHAs' interviews, it was noticed that there are other senses about HIV and AIDS, seropositivity and sexuality not covered by the campaigns. For us, this monological model - widely criticized by academic studies - is a consequence of the authorities' perception or of the official discourse that, outside scientific and specialized discourses, there is little to be heard.

We re-stress we are not saying that the analyzed campaign does not work to inform and to call people to prevent HIV. Rather, our focus was on understanding to what extent, despite efforts, there are still sense dissonances between what was intended by the producers of the campaign and what was perceived by the 'target audience'. This is because, discursively, one of the characteristics of language is the equivocation: the sense's possibility to always be another. There is a lot of discursive heterogeneity in the field of HIV - filled with disputes over senses, despite the centrality assumed by the campaigns, especially those of the State. When comparing the campaign with the discourses of the seropositive interviewees, it was able to identify some challenges to the biomedical discourse that are present in most preventive health campaigns, in general - mainly to the one that regulates which behaviors and actions are allowed and forbidden, making the individual responsible for the care of himself and of the others. We are witnessing a discursive struggle, in which both the individuals (in this case, the HIV-positive people) and the institutions (here, the Brazilian Ministry of Health) fight for the final word, for the hegemonic sense, for beliefs and convictions, for strategies and experiences.

\section{Conclusions}

This paper advocates the theoretical-methodological potentialities of Discourse Analysis in understanding resistances to health campaigns, and encourages its inclusion in the roll of methods for their evaluation. In order to bridge the gap between the messages and their target audience, people must be listened and recognized as subjects of discourse, and of legitimate discourses not "erratic or ignorant" ones. The willingness to listen to them is lacked, not expecting to hear what they should say, but rather how they construct the drift of senses, which comes to act exactly where institutional ideologies fail. But if they fail - for failure is inherent in ideology, in the institutionalized injunction of the senses - it is because the truth of 
the subject must reveal itself in this drift. The sense that determined the failure of the campaign and its possibility of reformulation may be in what has not been heard.

Therefore, before trying with campaigns to change individual's practices towards behaviors that promote health, our institutional practices must be changed, including prioritizing listening. If it is done, then a great step towards improving health campaigns will have been taken.

\section{Acknowledgments}

This study was financed in part by Coordenação de Aperfeiçoamento de Pessoal de Nível Superior - Brasil (CAPES) - Finance code 001.

\section{References}

Alves, M. R. A. B. (2015). Publicidade Governamental de Utilidade Pública na Área de Saúde: circuito configurado na instância das práticas de produção pelo processo de realização de uma campanha publicitária pelo Ministério da Saúde (Masters dissertation). Fundação Oswaldo Cruz, Rio de Janeiro.

Alves, W. (2013). Entre sentidos e desejos: as campanhas de carnaval para a prevenção contra o HIV (1999-2009). Libero (FACASPER), 16(31), 89-104. Accessed on 02 october 2018 from the World Wide Web: <http://seer. casperlibero.edu.br/index.php/libero/article/view/241>.

Araujo, I. S., \& Cardoso, J. M. (2007). Comunicação e Saúde. Rio de Janeiro, Brasil: Editora Fiocruz.

Bauman, A. (2000). Precepts and principles of mass media campaign evaluation in Australia. Health Promotion Journal of Australia, 10(2), 89-92.

Contrera, W. F. (2005). Histórico das Campanhas de Aids no Brasil. In A. Nilo, J. C. Veloso, L. Lindner, \& R. Duda (org.), Comunicaids: Políticas públicas e estratégias de controle social (pp. 41-50). São Paulo, Brasil: Ed. Ágil.

Costa, S. L. M. (2014). Comunicação, campanhas e bioidentidades: discursos sobre o HIV entre governos, OSCs e soropositivos (Masters dissertation), Universidade Federal de Juiz de Fora, Juiz de Fora, Minas Gerais. Accessed on 10 May 2015 from the World Wide Web: <http://bit.ly/1g2YIKW>.

Davey, M. (2012, May 4). Confusion reigns over HIV drugs. The Sidney Morning Herald. Accessed on 10 May 2012 from the World Wide Web: <http://bit.ly/KYvKQ2>.
Dorfman, L., Ervice, J., \& Woodruff, K. (2002, November). Voices for change: A taxonomy of public communications campaigns and their evaluation challenges. Berkeley, CA: Berkeley Media Studies Group.

European Centre for Disease Prevention and Control. (2014). A literature review on health communication campaign evaluation with regard to the prevention and control of communicable diseases in Europe: Insights into health communication. Accessed on 02 November 2018 from the World Wide Web: <https:// ecdc.europa.eu/sites/portal/files/media/en/publications/ Publications/Campaign-evaluation.pdf $>$.

Fernandes, G.C., Almeida, M. C., Pedroso, N.J., Keulen, M.S.L., Yokoo, E. M., \& Tuboi, S.H. (2013). The role of operational research to understand HIV/ AIDS regional healthcare system in Brazil and its importance to scaling-up antiretroviral therapy. Article presented at the event 30 years of HIV science: Imagine the future, Paris, France.

Foucault, M. (1999). História da sexualidade, vol. I: a vontade de saber (13th Ed.). (M. T. C. Albuquerque \& J. A. G. Albuquerque, Translators). Rio de Janeiro, Brasil: Edições Graal. (Original book published in 1976).

Foucault, M. (2000). Em defesa da sociedade: Curso no Collège de France (1975-1976). (M. E. Galvão, Translator). São Paulo, Brasil: Martins Fontes. (Original book published in 1997).

Guilhaumou, J. (2007). Efeito de sentido e visibilidade social: Co-construção discursiva. O espaço de coprodução no trabalho do pesquisador. In F. Indursky \& M. C. L. Ferreira (Org.), Análise do Discurso no Brasil: mapeando conceitos, confrontando limites (pp. 199206). São Paulo, Brasil: Claraluz.

Kong, M.C., Nahata, M.C., Lacombe, V.A., Seiber, E.E., \& Balkrishnan, R. (2012). Association Between Race, Depression, and Antiretroviral Therapy Adherence in a Low-Income Population with HIV Infection. Journal of General Internal Medicine, 27(9), 1159-1164. https:// doi.org/10.1007/s11606-012-2043-3.

Lima, C. R. M. (2006). Aids: uma epidemia de informações. São Paulo, Brasil: Ed. E-Papers.

Maksud, I. (2007). Casais Sorodiscordantes: Conjugalidade, Práticas Sexuais e HIVIAids (Doctoral thesis). Universidade Estadual do Rio de Janeiro, Rio de Janeiro. Accessed on 02 october 2018 
from the World Wide Web: <https://thesis.icict.fiocruz.br/ pdf/lviaMaksud_tese.pdf>.

Ministério da Saúde. (2010). Campanha de Carnaval - Camisinha. Com amor, paixão ou só sexo mesmo. Use sempre - 2010 [On-line video]. Available at: <https://youtu.be/pAOh6eEZP1M> [Access: 2018, October 02].

Ministério da Saúde. (2011). Pesquisa de Conhecimentos, Atitudes e Práticas na População Brasileira de 15 a 64 anos - 2008 (ResearchReport/2011), Brasília, DF, Secretaria de Vigilância em Saúde, Departamento de DST, Aids e Hepatites Virais. Accessed on 02 october 2018 from the World Wide Web:<http://bvsms.saude.gov.br/ bvs/publicacoes/pesquisa_conhecimentos_atitudes_ praticas_populacao_brasileira.pdf $>$.

Moulin, A. M. (2008). O corpo diante da medicina. In A. Corbin, J. Courtine \& G. Vigarello (Orgs.), História do corpo: As mutações do olhar. O século XX. (v. 3, pp. 15-82). Petrópolis, Brasil: Vozes.

National Cancer Institute. (2009). Making Health Communication Programs Work: U.S. Department of Health \& Human Services.

Noar, S. M. (2009). Challenges in evaluating health communication campaigns: Defining the issues. Communication Methods and Measures, 3(1-2), 1-11.

Noar, S.M. (2012). An Audience-Channel-MessageEvaluation (ACME) Framework for Health Communication Campaigns. Health Promotion Practice, 13(4), 481-8. doi: $10.1177 / 1524839910386901$

Noar, S. M., Palmgreen, P., \& Zimmerman, R. (2009). Reflections on evaluating health communication campaigns. Communication Methods and Measures, 3(1-2), 105-14.

ONU - Organização das Nações Unidas. (2011). Declaração Política sobre HIV/AIDS: Intensificando nossos Esforços para Eliminar o HIV/Aids. Resolução A/RES/65/277, adotada pela Assembleia Geral em 10 de junho de 2011. Accessed on 02 October 2018 from the World Wide Web: <https://unaids.org.br/wpcontent/uploads/2016/11/Declara\%C3\%A7\%C3\%A30Pol\%C3\%ADtica-sobre-HIV-VIH-AIDS-SIDA-2011PORTUGU\%C3\%8AS.pdf >.

Orlandi, E. L. P. (2004). Cidade dos Sentidos. Campinas, Brasil: Pontes.
Orlandi, E. L. P. (2005). Análise de discurso: princípios e procedimentos (6th ed.). Campinas, Brasil: Pontes.

PAZ, J. (2007). Aids anunciada: a publicidade e o sexo seguro. Brasília, Brasil: Editora UnB.

Pêcheux, M. (1997). Só há causa daquilo que falha ou o inverno político francês: início de uma retificação. In M. Pêcheux (Ed.), Semântica e discurso: uma crítica à afirmação do óbvio (pp. 293-307). Campinas, Brasil: Ed. Unicamp.

Rodrigues, F. D. (2012). Os enunciados das campanhas de prevenção à Aids no Brasil e seus dispositivos de produção de verdades no âmbito da saúde (Masters dissertation). Universidade Federal de Juiz de Fora, Minas Gerais.

Shannon, C. E., \& Weaver, W. (1949). The Mathematical Theory of Communication. Urbana, IL: University of Illinois Press.

Unaids - The Joint United Nations Programme on HIVI AIDS (2018). Undetectable = untransmittable: public health and HIV viral load suppression. Accessed on 02 November 2018 from the World Wide Web: <http://www. unaids.org/sites/default/files/media_asset/undetectableuntransmittable_en.pdf>

WHO - World Health Organization. (1986). The Ottawa Charter for Health Promotion. First International Conference on Health Promotion, Ottawa, 21 November 1986. Accessed on 02 October 2018 from the World Wide Web: <http://www.who.int/healthpromotion/conferences/ previous/ottawa/en/index2.html>. 